UDK: 177.7:929 Fromm, E. Pregledni članak Primljen 28. IV. 2019.

KREŠIMIR TABAK - IVICA MusiĆ Filozofski fakultet Sveučilišta u Mostaru kresimir.tabak@ff.sum.ba - ivica.music@ff.sum.ba

\title{
PLEMSTVO DUHA U FILOZOFIJI ERICHA FROMMA
}

\section{Sažetak}

U intelektualnome diskursu 20. stoljeća umnost kao univerzalnu kategoriju umnogome je zamijenila njezina instrumentalna inačica. U spomenutome stoljeću prevladava distopijska misao koja u život suvremenoga čovjeka unosi nihilizam i apsurd. Univerzalne životne vrijednosti kao vezivno tkivo civilizacije, ideal koji je bio trajno prisutan u povijesti ljudskoga roda, u suvremenome dobu više nisu na istaknutome mjestu. Unatoč tim nepovoljnim okolnostima svojim stvaralaštvom pojedini filozofi odgovorit će na moderne izazove i pokazati postojanje vrijednosti bez kojih civilizacija ne može opstati. Značajnik koji je afirmativno promišljao o životu i tragao za alternativom postojećemu stanju bio je i Erich Fromm. U radu se njegov esencijalizam povezuje s naširoko poznatim i primjenjivanim pojmom "plemstvo duha“. Također se opisuje Frommova kritika kapitalizma i socijalizma kao neodgovarajućih društvenih sustava. Modernoj stvarnosti koja se drži svijetom bez alternative u radu se suprotstavlja Frommova vizija ideala ljudske prirode, odnosno tip karaktera kojemu će biti cilj rast i razvoj svih čovjekovih mogućnosti. Među najvrjednije ljudske mogućnosti ubrajaju se produktivno mišljenje i produktivna ljubav. Najviši oblik produktivnosti pripisuje se revolucionarnomu karakteru, odnosno životnoj orijentaciji koja se identificira s čovječanstvom, rabi univerzalna mjerila te gaji sklonost i ljubav za život. 
Na kraju se zaključuje kako se bez duhovne plemenitosti ne može održati ni vizija zreloga života.

Ključne riječi: plemstvo duha; kapitalizam; socijalizam; produktivni karakter; ljubav; mišljenje

\section{Uvod}

Pitanje o čovjekovoj praktičnoj dimenziji i ispravnosti ljudskoga djelovanja svevremeno je pitanje, jednako živo na samome početku civilizacije kao i u naše vrijeme. U dobu ekstrema, kako 20. stoljeće naziva Eric Hobsbawm, ili u stoljeću straha, kako ga naziva Albert Camus, zavladala je epistemološka doktrina prema kojoj takvo pitanje uopće nije moguće postaviti, a kamoli na njega smisleno odgovoriti. Učinak takva načina mišljenja bit će pad civilizacije u barbarstvo. Povijest 20. stoljeća, u kojem nacistički „tisućljetni Reich“ i „komunistička utopija“ postaju sekularne alternative za protjeranu vječnost, to najbolje potvrđuje.

Interpretirajući riječi pjesnika Paula Celana, Rob Riemen tvrdi kako je u ovome dobu značenje riječi spaljeno te se zabrinuto pita kako će čovjek spoznati pravo značenje, vrijednost i istinu sada kada ih jezik više ne može izraziti. Na taj izazov i opću atmosferu apsurda životnim i intelektualnim naporom odgovarali su brojni umjetnici i filozofi. Unatoč okruženju totalitarizma i prividne znanstvenosti oni pokazuju postojanje univerzalnih vrijednosti bez kojih civilizacija ne može opstati. Redu tih mislitelja pripada i Erich Fromm.

Cilj je ovoga rada predstaviti filozofsku dimenziju Frommove misli. Nasuprot mračnoj atmosferi prošloga stoljeća ovaj značajnik afirmativno promišlja o životu i traga za alternativama postojećemu stanju. On također ukazuje na ideale (inherentne ljudskoj prirodi) koje je suvremeni život zaboravio, ideale na kojima je izrasla čitava civilizacija i ideale bez kojih je teško zamisliti budućnost. Ti su ideali, utkani u povijesti civilizacije, ovdje objedinjeni naširoko poznatim i primjenjivanim pojmom "plemstvo duha“. 


\section{Plemstvo duha kao civilizacijski ideal}

Plemstvo duha civilizacijski je ideal, trajno prisutan u povijesti ljudskoga roda, životima i opusima brojnih umjetnika i filozofa, od Homera do Kundere, od Sokrata do Chomskoga.

Za početak zapadnoeuropske uljudbe veže se nastanak Homerovih epopeja koje nas uvode u svijet junaštva, ali i svijet svih slabosti i ljudskih vrlina. Homerovi junaci, osim ukupnoga strasnog iživljavanja života, neprestano teže za mjerom i poretkom, za uljuđenošću i lijepom jasnoćom. Da bi netko u takvu svijetu postao heroj, nisu bile dovoljne fizička snaga i plemenitost po krvi, nego i ona po duhu bez koje, kako nas uči Homer, na duže vrijeme ne može opstati nijedna zajednica kao ni društveni poredak.

S animalnim afinitetima čovjeka, razornim strastima kao etički negativnim snagama, koji cio jedan narod uvaljuju u bijedu, obračunat će se liričari i tragičari, navlastito Sofoklo u Ajantu s jasnom ambicijom odvraćanja od antisocijalnih afekata, silovitih strasti i bijesne samovoljnosti poradi njegovanja vrlina građanskoga života: pravednosti, mudrosti, društvenosti, kao i svih onih koje unaprjeđuju život u politici.

Prvi sustavan i filozofski pristup o ispravnosti ljudskoga djelovanja, o zakonitostima društvenoga života i plemenitosti duha kao temeljnome uvjetu očuvanja i funkcioniranja ljudske zajednice svojim će životom i djelom nekoliko stoljeća poslije pokazati Sokrat kojega proročanstvo u Delfima proglašava najmudrijim čovjekom na zemlji, ne zbog onoga što je znao, nego zbog svijesti o vlastitoj kontingenciji ili, kako sam kaže, spoznaje da ljudska mudrost u odnosu na božansku vrijedi malo, štoviše - nimalo.

Sokratovom će se pojavom na povijesnoj sceni utemeljiti filozofska tradicija zapadnoga mišljenja koja će postati vrijednosnom osnovom većine budućih filozofskih sustava počevši od Platona i Aristotela, kao i kršćanski orijentiranih filozofa Aurelija Augustina i Tome Akvinskoga, zahvaljujući kojima će stečevine grčke kulture biti dostupne novovjekovlju, ali i današnjici. 
U egzistencijalnome i filozofskome pogledu Benedict de Spinoza bit će filozof koji će naslijediti Sokrata i zaključiti da bit slobode nije ništa drugo nego ljudsko dostojanstvo samo. Jedino onaj tko se odazove na čovjekov poziv da bude čovjekom, tko ne dopušta da njime zavladaju užitci, bogatstvo, častoljublje, moć i strah, već usvoji trajno, istinsko dobro i pusti da ga vode sloboda i istina, taj je stekao slobodu duha i poznaje istinsku slobodu.

Svojim kapitalnim djelom Etika, a posebno njegovim prvim poglavljem, Spinoza je odredio put Goetheovu stvaralaštvu, koji u autobiografskome djelu Dichtung und Wahrheit (1833.) za Spinozino poimanje dragocjene, teške i rijetke slobode rabi naziv Adel des Geistes. Poslije Goethea taj će pojam eksplicitno biti prisutan u stvaralaštvu Thomasa Manna koji upravo tu sintagmu rabi za zbirku svojih eseja: Adel des Geistes: Sechzehn Versuche zum Problem der Humanität. U engleskoj inačici, nobility of spirit, pojavljuje se i u filozofsko-političkoj esejistici Walta Whitmana Democratic Vistas, a suvremeno mu značenje daje živući nizozemski filozof Rob Riemen u djelu Adel van de geest.

Sadržaj ovoga ideala poslužit će kao ideja vodilja brojnih umjetnika i filozofa koji su djelovali potkraj 19. i tijekom čitavoga 20. stoljeća. Od poznatijih treba spomenuti Nicolaia Hartmanna i njegov pojam etički čovjek, kojemu je posvetio svoje opsežno djelo Etika, zatim Alberta Camusa koji modernomu beznađu suprotstavlja svojega pobunjenog čovjeka, što je i naziv filozofskoga eseja orijentirana na kulturnu situaciju Europe.

\section{Kritika modernoga društva}

Naša je civilizacija počela čovjekovim aktivnim ovladavanjem prirode, ali je to ovladavanje ostalo ograničeno do nastupa industrijskoga doba. Upravo britansku industrijsku i francusku buržoasku revoluciju povjesničar Eric Hobsbawm naziva dvojnom revolucijom te tvrdi da je „donijela najveću promjenu u ljudskoj povijesti, nakon dalekog vremena u kojem je čovjek počeo obrađivati zemlju i metale, izumio pismo te stvorio grad i državu. Ta je revolucija promijenila i nastavlja mijenjati 
cijeli svijet" ${ }^{\text {1. }}$ Nova situacija u povijesti sa sobom je donijela mnoštvo preoblikovanja: životinjsku i ljudsku energiju zamijenile su mehanička i kasnije atomska, ljudski um zamijenjen je računalom, stvorila se percepcija da je zavladala neograničena proizvodnja, pa prema tome i potrošnja, da je tehnika čovjeka učinila svemoćnim, a znanost sveznajućim. Kako bi Freud rekao, svojom stvaralačkom aktivnošću čovjek je postao sličan Bogu, a stvaranju i usavršavanju ne nazire se kraj. ${ }^{2}$

Uz sve preobrazbe koje su došle s industrijskom revolucijom posebnu pozornost zahtijeva jedna činjenica koju ističe Jose Ortega y Gasset, a ona se tiče porasta broja pučanstva u Europi. Po Gassetovim riječima od 6. stoljeća pa sve do 1800 . godine, dakle u punih dvanaest stoljeća, Europa je uspjela dosegnuti tek 180 milijuna ljudi, a od 180o. do 1914., dakle za nešto više od jednoga stoljeća, broj stanovnika u Europi porastao je sa 180 milijuna na 460 milijuna. Ta bujica nastala iz triju naraštaja u potpunosti je preplavila povijesno područje, a ovaj podatak o porastu stanovništva čini razumljivim pobjedu mase i sve što ona odražava i najavljuje. ${ }^{3}$ Nova populacija na povijesnoj sceni nije se mogla nahraniti tradicionalnom kulturom, nego je kreirala svoju vlastitu. Temelj novoga načina života čine hedonizam i egoizam, principi koji su cijeloj povijesti zapadne filozofije svoje teorijsko uporište nailazili jedino u Sokratova učenika Aristipa i francuskih materijalista poput La Mettriea koji je preporučivao uporabu droga i de Sadea koji je okrutne nagone smatrao legitimnim samo zato što postoje.

$\mathrm{Na}$ temeljima radikalnoga hedonizma i neograničenoga egoizma izrast će dva suprotstavljena tabora koja za sebe tvrde da mogu ispuniti sva čovjekova očekivanja. Riječ je o kapitalizmu i komunizmu. Da bi pronašao rješenje za ljudski problem, Fromm će propitati značajke i jednoga i drugoga. Razmatrajući kapitalističke mehanizme, slično Weberu zaključuje kako je koncentracija kapitala dovela do stvaranja divovskih poduzeća kojima upravljaju hijerarhijski organizirane birokracije. ${ }^{4}$

\footnotetext{
ErIC Hobsbawm, Doba revolucije, Školska knjiga, Zagreb, 1987., str. 21.

Usp. Sigmund Freud, Iz kulture i umetnosti, Matica srpska, 1979., str. 289.

Usp. Jose Oretga y Gasset, Pobuna masa, Golden marketing, Zagreb, 2003., str. 86.

4 Usp. Erich Fromm, On disobedience - Why freedom means saying "no" to power, Harper Collins e-books, London, 2010., str. 25.
} 
U takvu sustavu čovjek postaje zupčanik u stroju, a njegova je ukupna funkcija određena ukupnom strukturom organizacije u kojoj djeluje. Inicijativnost, odvažnost, individualnost i maštovitost, isto kao i solidarnost i ljubav, osobine su koje su strane ovomu društvenom modelu. Na njihovo mjesto dolazi uvjerenje da egoistično djelovanje donosi najbolje rezultate. Kao učinak dobivamo upravljanje ljudima kao da su stvari. To nije samo slučaj s proizvodnim institucijama, nego se gotovo sva udruženja pretvaraju u birokratske strojeve u kojima je čovjek minoriziran. Na mjesto njegove dobrobiti dolazi povećanje proizvodnje boljih stvari. Pojedincem se pak manipulira poticanjem njegovih apetita za novom robom usmjerujući ih tako da budu najprofitabilnije za industriju. ${ }^{5}$ Richard Sennett primjećuje kako potrošačka strast samu sebe sagorijeva vlastitom snagom što znači da suvremeni čovjek u uvjetima opće dinamike nema vremena uživati u onome što posjeduje. Stvari mnogo primamljivije izgledaju na izlozima nego u vlasništvu gdje gube svoju primamljivost, sagorijevaju i usmjeravaju potrošačevu pozornost na drugi objekt, pa tako u krug. ${ }^{6}$

Tako se čovjek iz građanina pretvorio u potrošača te je postao materijalno bogatiji i duhovno siromašniji. To će rezultirati čovjekovom nesigurnošću, usamljenošću, depresivnošću i sveopćim besmislom. Umjesto da bude gospodar strojeva koje je izgradio, čovjek je postao njihov rob, a ako ne promijeni svoj odnos prema životu i ne savlada stroj, potisnuta životna energija očitovat će se u destruktivnome obliku te će čovjek željeti uništiti život, a ne umrijeti od dosade. ${ }^{7}$

Kritizirajući kapitalističku praksu u kojoj stvari usmjeravaju život, socijalizam je na pozornicu izišao s idejom ljudske emancipacije, odnosno s ciljem ostvarenja ljudske individualnosti, a ne uniformiranosti. $\mathrm{Na}$ materijalne ciljeve u socijalističkoj doktrini gleda se kao na nešto što nije glavni ljudski problem, štoviše, socijalisti vjeruju kako materijalno bogatstvo korumpira čovjeka te nasuprot tomu ističu kako je njihov

Usp. isto, str. 27.

6 Usp. Richard Sennett, The culture of the new capitalism, Yale University Press, New Haven, 2006., str. 165 .

7 Usp. E. Fromm, On disobedience..., str. 29. 
prioritet produktivnost čovjeka kao osobe, a materijalna udobnost samo u mjeri u kojoj je u službi ostvarenja ljudskih ciljeva. Zalažu se za punu solidarnost svih ljudi i situaciju u kojoj se čovjek nikada neće tretirati kao sredstvo. U konačnici socijalistički se nauk usmjeruje na besklasno društvo u kojem će se pojedincu vratiti sloboda i inicijativnost. ${ }^{8}$

U stvarnosti ovaj je nominalno humanistički pokret podlegao duhu kapitalizma koji je želio zamijeniti. Pokret za oslobođenje čovjeka pretvorio se u pokret za gospodarsko poboljšanje radničke klase. Umjesto da nadiđe kapitalističku strukturu, socijalizam se pretvorio u njezina zagovornika te su se humanistički ciljevi zaboravili, naglasak se stavio samo na gospodarski dobitak. Radi brzoga nagomilavanja kapitala socijalizam su počeli prožimati teror i diktatura te se na kraju kreirao sustav koji je postao okrutniji od bilo kojega kapitalističkog oblika koji je, gledano u cjelini, ipak sačuvao neku vrstu političke slobode.

Usprkos pretencioznim ambicijama kapitalizma i komunizma Fromm smatra da su ta dva sustava tvorci novoga industrijskog feudalizma čije je vodstvo podleglo manipulaciji velike i moćne birokracije. U takvim sustavima „pojedinac je postao dobro nahranjen automat koji se zabavlja i pri tom gubi svoju individualnost, neovisnost i ljudskost" ${ }^{\text {"9 }}$. Radi što veće proizvodnje robe čovjek se odrekao svijeta solidarnosti i pravde te se taj ideal izgubio u praznome konceptu tehnološkoga napretka. I kapitalistički i komunistički menadžerski industrijalizam sustavi su u kojima okolnosti kontroliraju čovjeka, a ne čovjek njih. Gospodarsko bogatstvo i ljudsko ispunjenje kao da su postali nespojivi. Čovjek se pokazao tvorcem mnogočega, a izgubio je majstorstvo nad vlastitim stvaranjem te se jaz između njegovih intelektualnih postignuća i emocionalne i moralne zaostalosti iz dana u dan povećava.

Karakterne crte koje će proizići iz ovih sustava utemeljenih na gospodarskoj učinkovitosti Fromm će nazvati patogenima jer u konačnici rezultiraju bolesnim čovjekom i bolesnim društvom. ${ }^{10}$

Usp. isto, str. 32 .

9 Isto, str, str. 23.

1o Usp. E. Fromm, The sane society, Routledge, London, 1991., str. 4. 
O odnosu pojedinca i društva Fromm promišlja slično kao Platon koji u Državi kaže: „Znaš dakle, da nužno ima toliko vrsta i ljudskih ćudi, koliko ima vrsta državnih uređenja? Ili misliš, da državna uređenja nastaju odnekuda iz drva ili kamena, a ne iz ljudskih ćudi u državama. Te ćudi povlače sve ostalo za sobom kao uteg na vagi. (...) Dakle ako je uređenje država peterovrsno, bilo bi peterovrsno i duševno uređenje pojedinaca. ${ }^{\text {"11 }}$ Fromm pretpostavlja da se u jednome društvu oblikuju tipovi karaktera koji najbolje odgovaraju danim društvenim uvjetima. „Karakterna struktura prosječnog pojedinca i socijalno-ekonomska struktura društva, kojeg je taj pojedinac član, uzajamno su ovisni. Mješavinu psihičkog područja pojedinca i društveno-ekonomske strukture nazivam društvenim karakterom. ${ }^{{ }^{12}}$

Fromm dijeli karakterne orijentacije na neproduktivne i produktivne. Neproduktivni oslikavaju stvarno stanje te se u njihovu kreiranju Fromm ponajviše oslonio na Freuda koji je svojom teorijom evolucije libida, od oralno-receptivnoga, preko oralno-sadističkoga i analnoga do genitalnoga stupnja, implicitno izrazio postavku po kojoj se zdrav karakter razvija od pohlepnoga, surovoga, škrtoga do usvajanja jedne aktivne, neovisne usmjerenosti. Fromm govori o toj evoluciji od usmjerenosti na primanje, preko usmjerenosti na izrabljivanje, gomilanje, trgovanje do proizvodne orijentacije. ${ }^{13}$ Karakter produktivne orijentacije Frommova je zamisao o tome kakav čovjek treba biti.

\section{Produktivni karakter}

Stvarnošću 20. stoljeća dominiraju distopijski motivi, a gotovo čitav misaoni diskurs kreće se između Orwellova svijeta otrcanosti i bijede, neimaštine i oskudice te Huxleyeve zemlje bogatstva i rasipnosti, obilja i sitosti. Iako autori znanstvene fantastike, ova dva autora o modernome su svijetu po Frommovu mišljenju dali jasnije uvide nego većina profesionalnih psihologa i sociologa ${ }^{14}$ Ljudi Orwellova svijeta bili su tužni i

\footnotetext{
Platon, Država, VIII, 544 d - 544 e, Naklada Juričić d. o. o., Zagreb, 2009., str. 306.

E. Fromm, To have or to be, Continuum, London, 1997., str. 109.

E. Fromm, Psychoanalysis and zen buddhism, Open Road, New York, 2013., str. 51.

Usp. E. Fromm, The revolution of hope, Harper\&Row, London, 1970., str. 29.
} 
uplašeni, a oni koje je prikazao Huxley bili su bezbrižni i razigrani. Unatoč razlikama ova dva svijeta imaju mnogo zajedničkih detalja. Povezuje ih slutnja strogo kontroliranoga svijeta, društva u kojem je pojedinčeva sloboda svedena na privid ili na ništicu, uređenja u kojem male skupine drže sve uzde, a ostatak se čovječanstva kreće poput marioneta, ${ }^{15}$ Fromm bi rekao - pasivnih promatrača koji se nalaze izvan odgovorna odlučivanja. ${ }^{16}$ Najposlije, Orwella i Huxleya povezuje vizija svijeta u kojem je alternativa njemu samomu postala gotovo nezamisliva.

Od ove dominantne, distopijske vizije nije se odmaknula ni psihoanaliza pa Fromm kaže kako je Freud dao iznimno dobru analizu neurotičnoga karaktera (Freud bi rekao pregenitalnoga, a Fromm neproduktivnoga), ali je, frojdovski kazano, genitalni karakter, karakter normalne, zdrave i zrele osobe ostao na margini. O njemu znamo tek da je to struktura individuuma koja je funkcionalna u seksualnome i socijalnome smislu.

Nakon što je izložio tipove neproduktivne orijentacije te došao do zaključka kako su depersonalizacija, praznoća, besmisao života i automatizacija dovele individuuma do velikoga nezadovoljstva, Fromm je u istraživanju otišao korak dalje. Posvetio se naime karakteru produktivne orijentacije, a zamislio ga je kao svojevrstan ideal ljudske prirode, kao tip karaktera kojemu će rast i razvoj svih čovjekovih mogućnosti biti cilj, a sve druge aktivnosti bit će mu podređene.

Produktivna orijentacija osobnosti odnosi se na temeljni stav, na način odnošenja u svim područjima ljudskoga iskustva. Obuhvaća mentalne, emocionalne i ostale reakcije prema drugima, sebi i prema stvarima. Produktivnost je čovjekova sposobnost da može uporabiti svoje snage i ostvariti mogućnosti koje su mu svojstvene. To znači da čovjek bude slobodan, vođen razumom i jedinstven sa svojim snagama. ${ }^{17}$

Za nju je sposobno svako ljudsko biće ako nije mentalno ili emocionalno osakaćeno. Temeljitije opisujući pojam produktivnosti, Fromm tvrdi kako se on ne smije miješati s aktivnošću u modernome značenju

\footnotetext{
Usp. Zygmunt Bauman, Tekuća modernost, Pelago, Zagreb, 2011., str. 57.

Usp. E. Fromm, The revolution of hope, str. 2.

Usp. E. Fromm, Man for himself, Routledge, Abingdon, 2006., str. 84.
} 
te riječi jer takva vrsta aktivnosti najčešće znači neproduktivnost zato što sama motivacija nije intrinzična. ${ }^{18}$ Aktivnost u modernome značenju najčešće dovodi do materijalnoga uspjeha, a pojam produktivnosti ne podrazumijeva praktične rezultate nego stavove s načinom reagiranja i orijentacije prema svijetu i prema sebi u životnome procesu. Ovdje nije naglasak na čovjekovu uspjehu nego na njegovu karakteru.

Govoreći o učinku ljudske produktivnosti, Fromm kaže kako ona može proizvoditi materijalne stvari, umjetnička djela i misaone sustave, ali kao najvažniji entitet produktivnosti navodi samoga čovjeka. Stoga bismo mogli reći da je produktivnost aktivnost kojom čovjek gradi sam sebe oživljavanjem svojih emocionalnih i intelektualnih mogućnosti. ${ }^{19}$ To je proces koji traje cijeli ljudski život, djelatnost koja nije proizvoljna, nego prati određene zakonitosti. Fromm kaže: „Ljudska bića imaju specifičnu strukturu - kao i bića bilo koje vrste - i mogu napredovati samo u okvirima te strukture. Sloboda ne znači slobodu od svih vodećih principa, nego slobodu razvitka prema zakonima strukture ljudskoga postojanja (autonomna ograničenja). Ona znači pokoravanje zakonima koji upravljaju optimalnim ljudskim razvitkom. ${ }^{\text {“2o }}$

Stoga Lawrence Wilde s pravom tvrdi da je Frommova etika bliska komunitarizmu. Utemeljena je na snažnoj normativnoj teoriji ljudske biti te je kao takva hrabar i osvježavajući protuotrov postmodernističkomu relativizmu. ${ }^{21}$ Također, Frommovo zasnivanje normi djelovanja na strukturi ljudske prirode uvrštava ga u krug esencijalističkih mislitelja.

U daljnjemu objašnjavanju pojma produktivnosti Fromm se služi analogijom i vlastitu ideju produktivne orijentacije potkrjepljuje Aristotelovim učenjem tvrdeći kako je produktivnost jedan od temeljnih pojmova u Aristotelovu sustavu etike te je blisko povezan s pojmom vrline koja se ogleda u očitovanju ljudske biti. ${ }^{22}$ Ljudsku bit Aristotel je prikazao pojmom ergon, odnosno onom funkcijom koja razlikuje

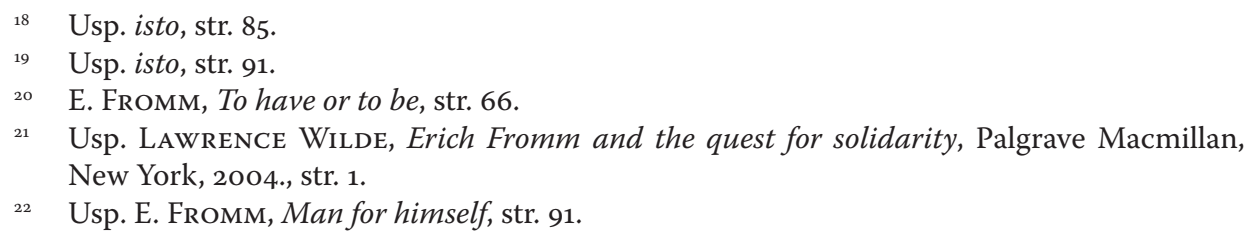


čovjeka od drugih živih bića. ${ }^{23} \mathrm{~S}$ biljkama čovjek dijeli rast i razvoj, sa životinjama dijeli osjetilnost, a svojstvo koje pripada čovjeku kao čovjeku jest razum. ${ }^{24}$ Tako je po Aristotelu dobar, ili frommovski kazano produktivan, onaj čovjek koji pod vodstvom najboljega dijela sebe (razuma) oživotvoruje mogućnosti svojstvene čovjeku. Oslonac svojoj ideji produktivnosti Fromm pronalazi i u Spinozinoj filozofiji u kojoj su vrlina i moć identični pojmovi. Sloboda i blaženstvo u Spinoze se očituje u čovjekovu nastojanju da ostvari svoj potencijal i da se približi modelu ljudske prirode. Čovjek vrline jest onaj koji rabi svoje moći, a poročan je onaj koji ih ne uspijeva uporabiti. ${ }^{25}$

$\mathrm{U}$ poetskoj formi ponajbolju ilustraciju produktivne aktivnosti Fromm primjećuje u Goethea i Ibsena. Goetheov Faust simbol je čovjekove vječne potrage za smislom života. U toj potrazi zadovoljstvo mu ne mogu pružiti ni znanost, ni užitak, ni moć, pa čak ni ljepota. Jedini odgovor na čovjekovo vječno pitanje nalazi se u čovjekovoj produktivnoj aktivnosti koja je identična s dobrim. Ibsenov Peer Gynt kao izniman predstavnik modernoga čovjeka živi u uvjerenju da su zarada i uspjeh najveća ljudska dostignuća, ali na kraju svoga života otkriva da su ga zarada i egoizam spriječili da postane osoba i da je ostvarenje vlastitosti moguće jedino ako je čovjek produktivan. Na kraju ga njegove neostvarene mogućnosti (misli, gesla, pjesme, suze i djela) optužuju i ukazuju mu na to kako je razlog njegova ljudskog neuspjeha upravo nedostatak produktivnosti. ${ }^{26}$

Nakon općega uvida u ideju produktivnosti Fromm razmatra njezino očitovanje u posebnim aktivnostima. Da bi čovjek opstao, prisiljen je povezivati se s drugim ljudima. Brojni su načini da to postigne, ali je samo jedan u kojem ostaje nepovrijeđen. Ljudskim životom vlada paradoks: $\mathrm{u}$ isto vrijeme mora težiti za bliskošću s drugima i za neovisnošću. Kako pripadati, a sačuvati autonomiju? To se može samo pomoću produktivnost ili, bolje rečeno, pomoću produktivna djelovanja i shvaćanja.

\footnotetext{
${ }_{23}$ Usp. RaymondPlant, Suvremena politička filozofija, Jesenski i Turk, Zagreb, 2002., str. 35.

24 Usp. Aristotel, Nikomahova etika, I 7, 1097b, 33 - 1098a, 8, Globus, Zagreb, 1988., str. 10.

25 Usp. Е. Fromm, Man for himself, str. 92.

26 Usp. isto, str. 94.
} 
Dvije se ljudske sposobnosti posebno ističu kada je riječ o shvaćanju svijeta: razum (mentalno) i ljubav (emocionalno). „Snagom razuma ljudi mogu prodrijeti kroz površinu pojava i tako razumjeti njihovu bit, a snagom ljubavi mogu se probiti kroz zid koji razdvaja jednu osobu od druge..." ${ }^{27}$ Iako su ova dva oblika shvaćanja svijeta izrazi različitih moći (emocije i mišljenja), jedna nije moguća bez druge. ${ }^{28}$

U modernome svijetu riječ ljubav dvosmislena je te izaziva najviše zbunjenosti, a uz to se i olako shvaća. Ljudi najčešće misle kako nema ništa lakše nego voljeti. Teškoća je u tome što neki ne mogu pronaći pravi predmet ljubavi, odnosno pravoga partnera. Za razliku od toga proizvoljnog tumačenja stvarnost je potpuno drukčija. Naime, iako svako ljudsko biće ima sposobnost voljeti, ostvarenje same ljubavi jedno je od najtežih postignuća. Fromm smatra da istinska ljubav svoj korijen ima u produktivnosti i stoga se može nazvati „produktivna ljubav“. „Iako se razlikuju objekti, snaga i kvaliteta ljubavi, postoje univerzalni elementi za sve forme produktivne ljubavi, a to su: briga, odgovornost, respekt i znanje." ${ }^{29}$

Briga i odgovornost pokazuju da je ljubav aktivnost, a ne strast kojom je netko obuzet. Najbolju ilustraciju ljubavi kao brige i odgovornosti Fromm pronalazi u knjizi proroka Jone u kojoj je vidljivo kako su ljubav i trud nerazdvojivi te da je bit ljubavi truditi se oko nečega i pomoći mu da raste. Po uzoru na Meistera Eckharta Fromm kaže kako čovjek voli ono oko čega se trudi i trudi se oko onoga što voli. Njemački bi mistik rekao: „Ljubav nas pretvara u ono što volimo." U navedenoj priči o Joni vidimo da ljubav ne može biti odvojena od odgovornosti, i to ne odgovornosti nametnute izvana, nego odgovornosti koja se osjeća kao vlastita briga. ${ }^{30}$

Voljeti osobu produktivno znači brinuti se i osjećati se odgovornim za njezin život, i to ne samo za njezinu fizičku egzistenciju, već za rast i napredak svih njezinih ljudskih moći. Produktivno voljeti nespojivo je s

27 Petteri Pietikainen, Alchemists of human nature, Pickering\&Chatto, London, 2007., str. 175 .

28 Usp. E. Fromm, Man for himself, str. 97.

29 Isto, str. 98.

30 Usp. isto, str. 99. 
pasivnošću, s tim da čovjek bude tek promatrač života ljubljene osobe. Produktivna ljubav podrazumijeva trud, brigu i odgovornost za njezin rast. Ljubav za čovjeka neodvojiva je od ljubavi za pojedinca. Voljeti neku osobu produktivno znači odnositi se prema njezinoj humanoj srži, prema njoj kao predstavniku čovječanstva. Ljubav za pojedinca, ako je odvojena od ljubavi za čovjeka, nužno ostaje površna. Svi ljudi trebaju pomoć i ovise jedni o drugima. Ljudska solidarnost nužan je uvjet da se bilo koji pojedinac ostvari.

Briga i odgovornost konstitutivni su elementi ljubavi, ali bez respekta prema ljubljenoj osobi i znanja o njoj ljubav se izopačuje i pretvara u dominaciju i posjedovanje. Respekt znači sposobnost da se osoba vidi onakvom kakva jest, da se bude svjestan njezine individualnosti i jedinstvenosti. ${ }^{31}$

U promišljanjima Maxa Horkheimera postoji razlikovanje između subjektivna i objektivna uma, onoga koji je usmjeren na djelomične ciljeve i onoga koji obuhvaća cjelinu..$^{32}$ Fromm također naglašava kako sama inteligencija može biti oruđe koje se rabi za iracionalne svrhe. Kaže i da je naše mišljenje najčešće zaokupljeno postizanjem praktičnih rezultata, s kvantitativnim i "površnim“ aspektima pojava, bez istraživanja valjanosti impliciranih ciljeva i pretpostavki i bez pokušaja da se shvati priroda i kvaliteta samih pojava. ${ }^{33}$

Razum po Frommovu mišljenju uključuje i treću dimenziju, dimenziju dubine, koja seže do biti stvari i procesa. Razum nije rastavljen od praktičnih životnih ciljeva, a nije ni oruđe za neposrednu akciju. Njegove su funkcije: znati, razumjeti, zahvaćati, odnositi se prema stvarima shvaćajući ih. On prodire kroz površinu stvari da bi otkrio njihovu bit, njihove skrivene odnose i dublja značenja, njihov „razlog“. Nije dvodimenzionalan, nego „perspektivan“, zahvaća sve zamišljene perspektive i dimenzije, a ne samo praktički relevantne. ${ }^{34}$

\footnotetext{
Usp. isto, str. 101.

Usp. MAX HorKheImer, Kritika instrumentalnoga uma, Globus, Zagreb, 1988., str. 8-9.

Usp. E. Fromm, Man for himself, str. 102.

Usp. isto.
} 
U produktivnu mišljenju subjekt nije ravnodušan prema svojemu objektu, nego je njime uzbuđen i zaokupljen. Što je odnos između subjekta i objekta intimniji, to je plodnije njegovo mišljenje. Objekt misli postaje nešto što je važan odnos našega interesa s motrišta njegova individualnog života ili uopće njegova postojanja. On na objekt gleda s brigom i odgovornošću. Također, produktivno mišljenje podrazumijeva i respekt, tj. sposobnost mislitelja da vidi objekt onakvim kakav on jest, a ne onakvim kakav bi želio da bude. Biti objektivan moguće je jedino ako respektiramo stvari koje promatramo, ako smo sposobni vidjeti ih u njihovoj jedinstvenosti i međusobnoj povezanosti. Bitan aspekt objektivnosti jest nužnost viđenja cjelovitosti fenomena. Ako promatrač izolira samo jedan aspekt objekta bez pogleda na cjelinu, neće pravilno razumjeti čak ni aspekt koji proučava. ${ }^{35}$

Pri proučavanju nije dovoljno gledati na objekt kakav on jest, nego i sebe vidjeti kakvi jesmo, odnosno moramo biti svjesni svojega mjesta u odnosu prema objektu. Važnost i ovisnost subjekta i objekta čini dvostruku determinaciju čiji je plod objektivnost koja se razlikuje od lažne subjektivnosti pri kojoj mišljenje nije kontrolirano objektom i tako degenerira do predrasude, proizvoljnosti i fantazije. Objektivnost za Fromma nije ni lažna ideja znanstvene objektivnosti koja je sinonim za ravnodušnost, odsutnost zanimanja i brigu. Objektivnost nije ravnodušnost, ona znači respekt, tj. sposobnost za nekrivotvorenje stvari, osobe i sebe. ${ }^{36}$

Fromm se suprotstavlja uvjerenju po kojemu je odsutnost osobnoga interesa uvjet za shvaćanje istine te navodi kako su svi važni uvidi i otkrića potaknuti interesom mislitelja. Mišljenje bez interesa sterilno je i besciljno. Pravo pitanje nije ima li interesa, nego kakav je njegov odnos prema istini. Svako produktivno mišljenje uvijek je stimulirano interesom promatrača, a ideje iskrivljuju oni interesi koji su nespojivi s istinom, s otkrivanjem objekta koji se promatra.

Tvrdnja da je produktivnost urođena ljudska sposobnost proturječna je ideji da je čovjek po prirodi lijen i da ga treba prisiliti na aktivnost.

Usp. isto, str. 104.

36 Usp. isto. 
Lijenost i prisilna aktivnost za Fromma su dva simptoma poremećaja čovjekova ispravnog funkcioniranja. $\mathrm{U}$ jedne vidimo nesposobnost za rad, a u druge nesposobnost za uživanje u miru i odmoru. Stoga se dade zaključiti da prisilna aktivnost nije suprotnost lijenosti, već njezina dopuna. Suprotnost objema jest produktivnost, a sakaćenje produktivne aktivnosti rezultira ili neaktivnošću ili prevelikom aktivnošću. Glad i prisila nikada ne mogu biti uvjeti za produktivnu aktivnost. Sloboda, gospodarska sigurnost i organizacija društva u kojem rad može biti smisleni izraz čovjekovih sposobnosti povoljni su čimbenici za izraz čovjekove prirodne tendencije da produktivno uporabi svoje snage. ${ }^{37}$ Produktivnu aktivnost karakterizira ritmičko smjenjivanje djelovanja i mirovanja. Da bi čovjek bio produktivan, volio i mislio produktivno, može jedino ako je sposoban biti smiren i sam sa sobom ili, drukčije rečeno, ako može biti nazočan ovdje i sada.

Najviši stupanj produktivnosti Fromm je nazvao revolucionarnim karakterom, a kako bi što bolje odredio njegovu bit, najprije je uklonio brojne atribute za koje bi se u nekomu kontekstu moglo pretpostaviti da pripadaju revolucionarnomu karakteru. On ne sudjeluje u revolucijama jer sudjelovanje u nečemu ne govori mnogo o karakternoj strukturi. Fromm također naglašava kako revolucionarni karakter nije ni buntovnik, a pod buntovnikom podrazumijeva čovjeka koji je ogorčen autoritetom, i to zato što ga autoritet ne cijeni, ne voli i ne prihvaća. Zbog svoje ogorčenosti buntovnik želi doći na mjesto autoriteta, a kada to postigne, najčešće se sprijatelji s onim autoritetom protiv kojega se ogorčeno borio. Kroz cijelu povijest mnogo je primjera kako su se pobune rabile da bi se postalo autoritet, a na politički život 20. stoljeća može se gledati kao na groblje s moralnim grobovima ljudi koji su počeli kao navodni revolucionari, a za kraće ili duže vrijeme pokazalo se kako su zapravo samo oportunistički buntovnici. ${ }^{38}$ Razvoj od buntovnika do autoriteta vjerojatno je ponajbolje opisao George Orwell u djelu Životinjska farma, romanu koji plastično pokazuje sve korake te preobrazbe.

Usp. isto, str. 107.

${ }_{38}$ E. Fromm, The dogma of Christ, and other essays on religion, psichology and culture, Routledge, Abingdon, 2006., str. 126. 
Za revolucionarni karakter Fromm tvrdi kako nije ni fanatik, a fanatika opisuje kao narcisoidnu osobnost koja se posvećuje određenomu cilju (političkomu, religioznomu...) te ga čini svojim idolom uveličavajući ga do apsoluta. Fanatik se može opisati simbolom gorućega leda, strastven i hladan istodobno. Takvi su uvijek igrali važnu ulogu u povijesti, a odavala ih je njihova hladna strast. Proroci su takve nazivali idolopoklonicima. ${ }^{39}$

Sama riječ „revolucionaran“ za Fromma ima pozitivne konotacije borbe za neovisnost i slobodu, a te atribute pripisuje i revolucionarnomu karakteru. Atributi sloboda i neovisnost nekada su bili ljudski ideali, međutim u suvremenoj demokraciji kao novome obliku porobljavanja oni se zlorabe. Po Frommovu mišljenju puna sloboda i neovisnost postoje samo kada individuum misli, osjeća i odlučuje za sebe. To čini autentično samo kada doseže produktivan odnos prema svijetu jer produktivnost omogućuje autentičnu reakciju. ${ }^{40}$

Revolucionarni je karakter onaj koji se identificira s čovječanstvom te stvarnost mjeri univerzalnim mjerilima. U njemu se primijeti i duboko poštovanje prema životu te duboka sklonost i ljubav prema životu. Redovito u kritičkome raspoloženju, sumnjičav prema svemu, ali ne i ciničan, revolucionarni karakter u pitanje posebno dovodi javno mnijenje. Ovaj tip karaktera nije prvotno politički pojam. Istina, on postoji u politici, ali postoji i u religiji, umjetnosti i filozofiji. Kao živi primjer Fromm navodi Isusa za kojega kaže da se kritički odnosio prema prihvaćenim vrijednostima. Tu ubraja Sokrata i proroke te sve ljude koje poštujemo, a najčešće ih hvalimo kada pouzdano znamo da su dovoljno dugo mrtvi. Kada je riječ o moći, ona za revolucionarni karakter nikada ne postaje sveta i nikada ne preuzima ulogu istine ili dobrote. Upravo je odnos prema moći jedan od najvažnijih problema današnjice, a onaj koga moć moralno impresionira nikada ne može biti kritički raspoložen ni revolucionarni karakter. ${ }^{41}$

\footnotetext{
$39 \quad$ Isto.

$40 \quad$ Isto, str, 128.

${ }_{41} \quad$ Usp. isto, str. 134.
} 
Frommova „revolucionara“ karakterizira i osobina nepokornosti, ali ne i anarhičnosti. On prati svoja načela, ali je spreman svakomu autoritetu reći ne. Pri procjeni kolika je u 20. stoljeću mogućnost za razvoj revolucionarna karaktera Fromm nastupa apokaliptično. Misleći na Prometeja te Adama i Evu, kaže kako je ljudska povijest počela činom nepokoravanja, a mogla bi završiti činom pokoravanja. ${ }^{42}$ Kao najveći problem suvremenoga čovjeka ističe kako je on čovjek organizacije, biće sustava goleme birokracije, sustava u kojem banalnost zla postaje pravilo. Ljudima se više ne vlada silom nego manipulacijom. Čovjek se pokorava, a da toga nije ni svjestan, štoviše, pokoravanje se tumači kao nešto u skladu sa zdravim razumom. ${ }^{43}$ Zbog tih razloga suvremenomu je čovjeku znatno teže usvojiti osobine revolucionarna karaktera nego ljudima prethodnih epoha. Činjenica je da nikada većina ljudi nije pripadala ovomu tipu karaktera, ali upravo zahvaljujući onima koji jesu, više ne živimo u pećinama, barem u fizičkome smislu.

\section{Zaključak}

U fluidnoj modernosti orijentiranoj na imanje, novo i senzualno sve su vrijednosti na kojima je utemeljena naša civilizacija pale u zaborav. O tome vjerojatno ponajbolje svjedoče riječi Maxa Horkheimera koji kaže kako doktrine poput pragmatizma odražavaju društvo koje nema vremena za sjećanje i razmišljanje. Stoga se pred suvremenoga čovjeka postavlja pitanje kuda ide, naprijed $\mathrm{k}$ humanitetu ili natrag $\mathrm{k}$ divljaštvu. Nakon strahota koje su se dogodile u 20. stoljeću čovjek se kao moralni djelatnik našao u situaciji koja se može usporediti s apokrifnom pričom koja opisuje stanje u kojemu su izgorjeli svi primjerci Tore te je prorok Ezra po Božjoj zapovijedi sve ponovno zapisao. S misijom proroka Ezre mogu se usporediti i Frommov intelektualni rad kao i plodovi toga rada. U atmosferi kojom prevladava apsurd Fromm ukazuje na brojne načine pomoću kojih možemo upoznati buduće naraštaje sa živim i povijesnim značajnicima koji pokazuju što ljudi mogu postići kao ljudi, a ne kao

\footnotetext{
Usp. isto, str. 135.

43 Usp. isto, str. 136.
} 
zabavljači. Ukazuje i na činjenicu da velika literarna i umjetnička djela svih vremena čine osnovicu za razdvojbu između dobrobitna i štetna djelovanja. Ako se vizija zreloga života ne održi, velika je vjerojatnost da će se naša kulturna tradicija slomiti. Ta se tradicija ne zasniva najprije na prijenosu stanovitih vrsta znanja, nego na prijenosu stanovitih ljudskih osobina. Ne budu li naraštaji koji dolaze više uočavali te osobine, pettisućgodišnja će kultura nestati, makar se njezino znanje prenosilo i dalje razvijalo.

To je pitanje u drami Browningova verzija ponajbolje postavio profesor Crocker Harris koji kao predavač klasičnih jezika postaje suvišan jer na mjesto njegovih predmeta dolaze šport, moderni jezici i eksperimentalna znanost. U svojemu oproštajnom govoru ovaj profesor kolegama, učenicima i njihovim roditeljima postavlja pitanje: „Kako se možemo nadati odgojiti civilizirane ljude ako više ne vjerujemo u civilizaciju?" To pitanje otvoreno je i osamdeset godina nakon praizvedbe spomenute drame, a od odgovora će umnogome ovisiti tijek društvenih zbivanja.

\section{Literatura}

- Aristotel, Nikomahova etika, Globus, Zagreb, 1988.

- Bauman, Zygmunt, Tekuća modernost, Pelago, Zagreb, 2011.

- Freud, Sigmund, Iz kulture i umetnosti, Matica srpska, Beograd, 1979.

- Fromm, Erich, Man for himself, Routledge, Abingdon, 2006.

- Fromm, Erich, On disobedience - Why freedom means saying "no" to power, Harper Collins e-books, London, 2010.

- Fromm, Erich, Psychoanalysis and zen buddhism, Open Road, New York, 2013.

- Fromm, ERICH, The dogma of Christ, and other essays on religion, psichology and culture, Routledge, Abingdon, 2006.

- Fromm, Erich, The revolution of hope, Harper\&Row, London, 1970. 
- Fromm, Erich, The sane society, Routledge, London, 1991.

- Fromm, Erich, To have or to be, Continuum, London, 1997.

- Gasset, Jose Oretga y, Pobuna masa, Golden marketing, Zagreb, 2003.

- Hobsbawm, Eric, Doba revolucije, Školska knjiga, Zagreb, 1987.

- Horkheimer, Max, Kritika instrumentalnoga uma, Globus, Zagreb, 1988.

- Pietikainen, Petteri, Alchemists of human nature, Pickering\&Chatto, London, 2007.

- Plant, Raymond, Suvremena politička filozofija, Jesenski i Turk, Zagreb, 2002.

- Platon, Država, Naklada Juričić d. o. o., Zagreb, 2009.

- Sennett, Richard, The culture of the new capitalism, Yale University Press, New Haven, 2006.

- Wilde, LAWRENCE, Erich Fromm and the quest for solidarity, Palgrave Macmillan, New York, 2004. 
Krešimir TABAK - IVICA Musić

University of Mostar, Faculty of Humanities and Social Sciences

\section{NOBILITY OF SPIRIT IN THE PHILOSOPHY OF ERICH FROMM}

\section{Abstract}

Wisdom as the universal category was mostly replaced by its instrumental variant in the intellectual discourse of the $2 \mathrm{O}^{\text {th }}$ century. Dystopian thought, that brings nihilism and absurd in the life of a contemporary man, dominated in the mentioned century. Universal life values as the connective tissue of the civilization, ideal which was permanently present in history of the human race, is not on the prominent place in modern era. Despite those unfavorable circumstances certain philosophers will answer to modern challenges through their creativity and show the existence of values the civilization cannot live without. Erich Fromm was an important person who was thinking about life in affirmative way and searching for the current status alternative. This paper connects his essentialism with the widely known and applicable term "nobility of spirit”. It also describes Fromm's critics of capitalism and socialism as unsuitable social systems. Fromm's vision of the ideal human nature or the character type whose aim are growth and development of all human capabilities is opposed to the modern reality which is considered as the world without alternative. Productive thinking and productive love belong to the most valuable human capabilities. The highest form of productivity is attributed to the revolutionary character or life orientation which is identified with mankind, it uses universal criteria and nourishes propensity and love for life. It is concluded in the end that the vision of mature life cannot last without spiritual nobility.

Keywords: nobility of spirit; capitalism; socialism; productive character; love; opinion 